\title{
BIOACCUMULATION AND DISTRIBUTION OF SOME HEAVY METALS IN THE WATER AND THE \\ NILE TILAPIA (OREOCHROMIS NILOTICUS) \\ FROM LAKE MANZALA, EGYPT
}

Khalil, M.T. ${ }^{(1)}$; Yehia, M. M. ${ }^{(2)}$; Gad, Nahed, Sh. ${ }^{(3)}$;

Sayed, M. M. ${ }^{(1)}$ and Ibrahim, H. M. ${ }^{(2)}$

1) Faculty of Science, Ain Shams University,Egypt 2) Central Laboratory for Environmental Quality Monitoring, National Water Research Center, Egypt 3) National Institute of Oceanography and Fisheries, Egypt

\begin{abstract}
Lake Manzala is one of the economic lakes and one of the most important Delta wetlands in Egypt, due to its high productivity. The southern region of the Lake receives agriculture, industrial and sewage wastewaters without treatment from several drains; the most polluted one is Bahr El-Baqur drain. In the present study the distribution and accumulation of some heavy metals ( $\mathrm{Al}, \mathrm{As}, \mathrm{Cr}, \mathrm{Co}, \mathrm{Ni}$ and $\mathrm{Se}$ ) were studied in the water and the Nile Tilapia O. niloticus, during the period from winter 2012 to autumn 2013. Results showed that the concentrations of heavy metals in water followed the order $\mathrm{Al}>\mathrm{Ni}>\mathrm{Cr}$. Heavy metals $\mathrm{As}, \mathrm{Co}$ and $\mathrm{Se}$ were not detected in all water samples at the six selected sites. Al and Ni levels in water were higher than the international permissible limits of Australia and New Zealand. The levels of the heavy metals in gills and muscles of the Nile Tilapia followed the order $\mathrm{Al}>\mathrm{Ni}>\mathrm{Co}>\mathrm{As}>\mathrm{Se}$ and $\mathrm{Cr}$. The concentrations of heavy metals exceeded the maximum permissible limits in all fish muscles. So, it can be conclude that the southern area of Lake Manzala is contaminated by high levels of heavy metals and the consumption of its fish is


J. Environ. Sci.

Institute of Environmental Studies and Research - Ain Shams University

not safe and could cause health hazard to the local population as their diet depends mainly on fish.

Keywords: heavy metals, Lake Manzala, Bahr El-Baqur drain, Oreochromis niloticus.

\section{INTRODUCTION}

Lake Manzala is bounded by Mediterranean Sea to the north, the Suez Canal to the east, Damietta governorate to the west, Dakahlia and Sharkia governorates to the south. Now, the Lake is considered as a sink for disposing industrial and human wastes. A total amount of 7500 million cubic meters of untreated industrial, sewage and agricultural drainage water is discharged annually into the lake via numbers of drains (Abdel-Shafy and Aly, 2002). The main drains are Bahr ElBaqur, Hadous and Ramsis. Bahr El-Baqur is considered as one of the most polluted drains in Egypt. It receives and carries the greatest part of wastewater ( 3 billion $\mathrm{m}^{3} /$ years) into the lake through a very densely populated area of the Eastern Delta passing through Qalubyia, Sharkia, Ismaillia and Port Said Governorates ( Zahran et al., 2015). Bahr ElBaqur drain has received considerable concern by Abdel-Azeem et al. (2007), Ali (2008) and Hamed et al., (2013)

Several investigations have been carried out concerning its ecosystem. These studies dealt with different environmental aspects of the Lake, including geological, aspects, hydrological regime, physicochemical properties, bacterial indices, phytoplankton composition, benthic invertebrates and fishery status (Abbassy et al., 2003; Gad, 2005; Ali, 2008) 
Additional recent information is needed to provide detailed database for water quality status that help in the proper management of the lake.

\section{Therefore, the objectives of this study are:}

1) To assess some heavy metals ( $\mathrm{Al}, \mathrm{As}, \mathrm{Cr}, \mathrm{Co}, \mathrm{Ni}$ and $\mathrm{Se}$ ) in the water and the Nile Tilapia Oreochromis niloticus collected from southern area of Lake Manzala and Bahr EL-Baqur drain.

2) To study the direct and indirect effect of sewage, industrial and agricultural wastewaters on the environmental condition of the Lake.

\section{MATERIAL AND METHODS}

1-Study area: Lake Manzala is located in the north-eastern corner of the Nile Delta. It is generally has a rectangular shape; about $60 \mathrm{~km}$ long and $40 \mathrm{~km}$ wide, and has an average depth of $1.3 \mathrm{~m}$. A total of $3.7 \mathrm{~km}^{3}$ of draiage water flows annually into Lake Manzala from nine major drains and canals. The most important of these are Al Serw, Baghous, Abu Gurida and Bahr El-Baqur. Bahr El-Baqur drain is the most polluted one as it carries a mixture of treated and untreated wastewater originating from Greater Cairo area and contributes in deteriorating water quality of the Lake.

2-Water Samples:Water samples were collected from six selected stations (figure 1 and table 1) during the period from winter 2012 to autumn 2013 from a depth of $50 \mathrm{~cm}$ in clean plastic bottles and acidified with few drops of concentrated nitric acid to reduce the $\mathrm{pH}$ 
below 2 to prevent the microbial reactions. The samples were transferred to the laboratory and kept refrigerated for later analysis (APHA, 2012).

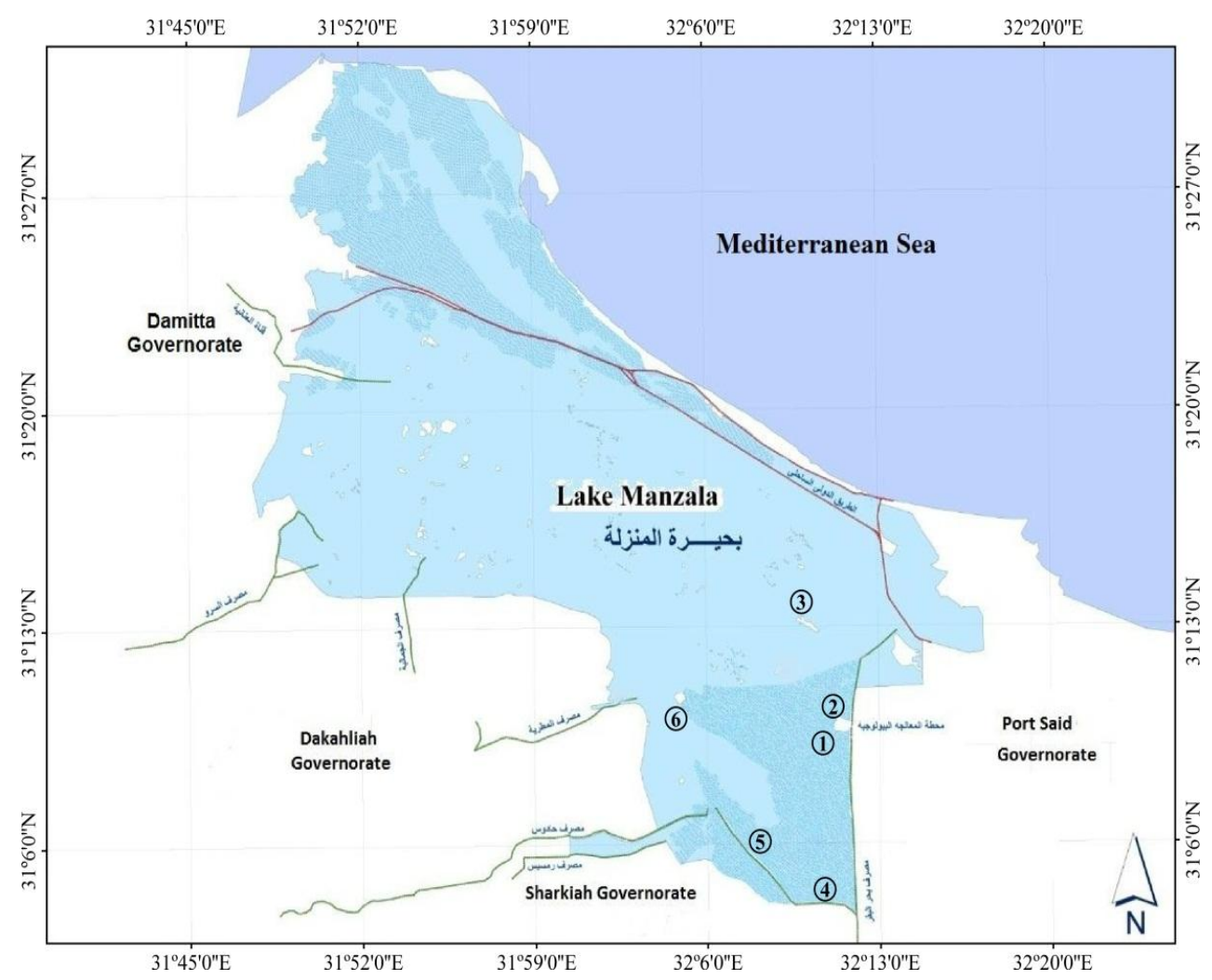

Figure (1): A map of Lake Manzala showing the sampling sites 
Table (1): Locsites and coordinates.

\begin{tabular}{|c|c|c|}
\hline sampling site & Location & Coordinates \\
\hline 1 & $\begin{array}{l}\text { End of Bahr El-Baqur drain before } \\
\text { Engineered Wetland Station }\end{array}$ & $\begin{array}{l}31^{\circ} 09^{\prime} 56^{\prime \prime} \\
32^{\circ} 04^{\prime} 54^{\prime \prime}\end{array}$ \\
\hline 2 & $\begin{array}{l}\text { Effluent of Engineered wetland } \\
\text { Station after treatment }\end{array}$ & $\begin{array}{l}31^{\circ} 10^{\prime} 23^{\prime \prime} \\
32^{\circ} 12^{\prime} 33^{\prime \prime}\end{array}$ \\
\hline 3 & Inside the Lake North of Site No.2 & $\begin{array}{l}31^{\circ} 10^{\prime} 08^{\prime \prime} \\
32^{\circ} 15^{\prime} 21^{\prime \prime}\end{array}$ \\
\hline 4 & $\begin{array}{l}\text { End of Bahr El-Baqur drain before } \\
\text { discharge to the lake }\end{array}$ & $\begin{array}{l}31^{\circ} 04^{\prime} 07^{\prime \prime} \\
32^{\circ} 10^{\prime} 37^{\prime \prime}\end{array}$ \\
\hline 5 & $\begin{array}{l}\text { Inside the Lake downstream Bahr El- } \\
\text { Baqur drain }\end{array}$ & $\begin{array}{l}31^{\circ} 07^{\prime} 31^{\prime \prime} \\
32^{\circ} 06^{\prime} 02^{\prime \prime}\end{array}$ \\
\hline 6 & Inside the Lake North of Site No.5 & $\begin{array}{l}31^{\circ} 10^{\prime} 11^{\prime \prime} \\
32^{\circ} 03^{\prime} 36^{\prime \prime}\end{array}$ \\
\hline
\end{tabular}

3-Fish Samples: $O$. niloticus fish samples were collected seasonally from the selected four sampling sites $(1,3,4,6)$ (Table 1) during the same period from winter 2012 to autumn 2013; the collected fish has a length of $20-30 \mathrm{~cm}$ and a weight of 150-250 g . After fish dissection, muscles and gills of the fish were carefully separated out of body

\section{4- Heavy Metals analysis:}

\section{1. in Water:}

Heavy metal and trace element concentrations in water were determined as a total concentration using the Inductively Coupled Plasma-Optical Emission Spectrometer (ICP-OES) with (Perkin Elmer optima model 5300). The samples were prepared and analyzed for ( $\mathrm{Al}$, As, Cr, Co, Ni, and Se) as to Standard Methods for (APHA, 2012). The concentrations were expressed in $\mathrm{mg} / \mathrm{L}$ and the detection limit is 0.001 $\mathrm{mg} / \mathrm{l}$ 


\section{2. in Fish tissues:}

Tissue samples (muscles and gills) were dried in an oven at $105^{\circ} \mathrm{C}$ for 24 hours ground to fine powder then digested according to the method described by Hamed et al., (2013). Heavy metals Al, As, Cr, $\mathrm{Co}, \mathrm{Ni}$, and $\mathrm{Se}$ in fish tissues were analyzed by using (ICP-OES), and expressed in $\mu \mathrm{g} / \mathrm{g}$ dry wt.

\section{RESULTS AND DISCUSSION \\ 1- Heavy Metals Concentration in Water Samples}

Accumulation of toxic metals of hazards level in aquatic biota has become a problem of increasing concern and could lead to health hazards in man either through drinking of water and/or consumption of fish.

1.1. Aluminum (Al): Table (2) shows the concentration of aluminum (Al) in water samples collected from different sites of Lake Manzala during the period from winter 2012 to autumn 2013. Al concentrations in the lake fluctuated between $(0.59 \pm 0.01)$ to $(1.87 \pm$ 0.02) $\mathrm{mg} / \mathrm{l}$. Highest concentration was recorded in site (1) in winter and the lowest was recorded in Site (2) in summer which facing effluent of engineered wetland status after treatment. 
Table (2): Seasonal Variations of aluminum (Al) concentration (mg/l) in water samples from Lake Manzala

\begin{tabular}{|c|c|c|c|c|}
\hline Seasons & Winter & Spring & Summer & Autumn \\
\cline { 1 - 1 } sampling site & & $1.54 \pm 0.08$ & $0.87 \pm 0.03$ & $1.08 \pm 0.05$ \\
\hline \hline 1 & $0.84 \pm 0.06$ & $1.20 \pm 0.10$ & $0.59 \pm 0.01$ & $1.04 \pm 0.02$ \\
\hline 2 & $1.20 \pm 0.10$ & $1.40 \pm 0.02$ & $1.79 \pm 0.04$ & $1.20 \pm 0.01$ \\
\hline 3 & $1.8 \pm 0.04$ & $1.84 \pm 0.06$ & $1.59 \pm 0.03$ & $1.3 \pm 0.02$ \\
\hline 4 & $1.45 \pm 0.13$ & $1.84 \pm 0.02$ & $1.70 \pm 0.02$ & $1.35 \pm 0.06$ \\
\hline 5 & $1.42 \pm 0.00$ & $1.71 \pm 0.01$ & $1.77 \pm 0.03$ & $1.23 \pm 0.20$ \\
\hline 6 & \multicolumn{3}{|l}{} \\
\hline
\end{tabular}

The increased metal concentration in winter and decreased in summer is in agreement with the results obtained by Saeed and Shaker (2012) and Ali (2008) who reported that heavy metals concentrations showed seasonal variation being greater in winter and lowest in summer. This may be attributed to the phytoplankton growth which was higher in summer and autumn seasons that can absorb large quantities of heavy metals from water. Also, the decreased heavy metals in summer and spring are due to its adsorption into the clay particles and then sedimentation to the underlying sediment (Ali and Fishar, 2005).

This variation may be due to difference in the sources of $\mathrm{Al}$ pollution and physical-chemical conditions of water. It was noticed that Al concentrations in Lake Manzala water have exceeded the world permissible limits $(1 \mu \mathrm{g} / \mathrm{l}$ at, $\mathrm{pH} 6.5$ and $55 \mu \mathrm{g} / \mathrm{l}$ at $\mathrm{pH}$ 6.5) reported by Ontario Ministry of Environment (ANZECC and ARMCANZ, 2000). 
1.2.Chromium (Cr) Table (3) shows the concentrations of chromium (Cr) in water samples collected from different sites of Lake Manzala during the period from winter 2012 to autumn 2013. The highest concentration $(0.113 \pm 0.006) \mathrm{mg} / \mathrm{l}$ was recorded in site (1) in winter and the lowest $(0.008 \pm 0.001) \mathrm{mg} / \mathrm{l}$ in site (4) in summer.

Table (3): Seasonal Variations of Chromium (Cr) concentration (mg/l) in water samples from Lake Manzala

\begin{tabular}{|c|c|c|c|c|}
\hline Seasons & Winter & Spring & Summer & Autumn \\
\cline { 1 - 4 } Sampling site & & & & \\
\hline \hline 1 & $0.113 \pm 0.006$ & $0.083 \pm 0.006$ & $0.009 \pm 0.01$ & $0.090 \pm 0.01$ \\
\hline 2 & $0.063 \pm 0.006$ & $0.087 \pm 0.006$ & $0.009 \pm 0.01$ & $0.070 \pm 0.006$ \\
\hline 3 & $0.073 \pm 0.006$ & $0.063 \pm 0.006$ & $0.033 \pm 0.01$ & $0.013 \pm 0.001$ \\
\hline 4 & $0.080 \pm 0.001$ & $0.069 \pm 0.001$ & $0.008 \pm 0.001$ & $0.030 \pm 0.001$ \\
\hline 5 & $0.078 \pm 0.001$ & $0.073 \pm 0.005$ & $0.031 \pm 0.01$ & $0.014 \pm 0.002$ \\
\hline 6 & $0.014 \pm 0.001$ & $0.065 \pm 0.004$ & $0.033 \pm 0.01$ & $0.017 \pm 0.001$ \\
\hline
\end{tabular}

Chromium does not occur freely in nature. The main chromium mineral is chromite. Chromium compounds can be found in waters only in trace amount (Authman, 2015). Cr concentration in all water samples collected from different sites of Lake Manzala still below the permissible limits $(0.5 \mathrm{mg} / \mathrm{l})$ recommended by ANZECC and ARMCANZ(2000).

\subsection{Nickel (Ni)}

Nickel released from the process of nickel mining and by industries that convert scrap or new nickel into alloys or nickel compounds or by industries that use nickel and its compounds. These industries may also 
discharge nickel into wastewaters. Once Nickel released to the environment it forms complexes with many ligands, making it more mobile than most heavy metals (Palaniappan and Karthikeyan, 2009). While Nickel is an essential element at low concentrations for many organisms, it is toxic at higher concentrations; exposure to Nickel may lead to various adverse health effects such as nickel allergy, contact dermatitis and organ system toxicity. The effect of Nickel on freshwater fishes was studied by Al-Attar (2007) who reported that sublethol concentrations of Nickel causes a decreased in serum $\mathrm{Na}+$ and osmolarity and increase in serum glucose, cholesterol, Triglycerids, AIT, AST and total protein of $O$. niloticus.

Table (4) shows the concentrations of nickel (Ni) in water samples collected from different sites of Lake Manzala during the period from winter 2012 to autumn 2013. nickel (Ni) concentration ranged from $(0.15 \pm 0.01)$ to $(0.63 \pm 0.06) \mathrm{mg} / \mathrm{l}$. Highest concentration $(0.63 \pm 0.06)$ $\mathrm{mg} / \mathrm{l}$ was recorded at site $(1)$ in winter and the lowest $(0.15 \pm 0.01) \mathrm{mg} / \mathrm{l}$ was recorded at sites $(2 \& 5)$ in summer.

Table (4): Seasonal Variation of nickel (Ni) concentration $(\mathrm{mg} / \mathrm{l})$ in water samples from Lake Manzala

\begin{tabular}{|c|c|c|c|c|}
\hline Seasons & \multirow{2}{*}{ Winter } & Spring & Summer & \multirow{2}{*}{ Autumn } \\
\hline Sampling sites & & & & \\
\hline 1 & $0.63 \pm 0.06$ & $0.52 \pm 0.02$ & $0.22 \pm 0.01$ & $0.34 \pm 0.01$ \\
\hline 2 & $0.42 \pm 0.02$ & $0.38 \pm 0.01$ & $0.15 \pm 0.01$ & $0.27 \pm 0.01$ \\
\hline 3 & $0.21 \pm 0.01$ & $0.16 \pm 0.01$ & $0.18 \pm 0.01$ & $0.18 \pm 0.01$ \\
\hline 4 & $0.56 \pm 0.01$ & $0.28 \pm 0.01$ & $0.19 \pm 0.01$ & $0.23 \pm 0.01$ \\
\hline 6 & $0.29 \pm 0.01$ & $0.23 \pm 0.01$ & $0.15 \pm 0.01$ & $0.19 \pm 0.01$ \\
\hline \hline
\end{tabular}


$\mathrm{Ni}$ concentrations in water of Lake Manzala are higher than the permissible level $(0.02 \mathrm{mg} / \mathrm{l})$ recommend by ANZECC and ARMCANZ (2000).The abundance of heavy metals in water samples collected from different sites of Lake Manzala followed the order $\mathrm{Al}>\mathrm{Ni}>\mathrm{Cr}$. Co and trace elements (As, and $\mathrm{Se}$ ) were less than the detection limits $(0.001 \mathrm{mg} / \mathrm{l})$ of the instrument (ICP-OES) in all water samples collected from different sites of Lake Manzala during all seasons.

\section{2- heavy metals in fish tissues}

Heavy metals are considered the most important element of pollution in the aquatic environment because of their toxicity and accumulation in organisms like fish and then go to man. Fish accumulated heavy metals to concentration higher than that present in water (Boran and Altinok , 2010).

Heavy metals accumulated in fish tissues through two mechanisms namely bio-concentration (uptake form the surrounding environment and bio-magnification (uptake through the food chain). Bioaccumulation occurs when an organism absorbs a toxic substance at a rate greater than that at which the substance is lost. Bioaccumulation results from a dynamic equilibrium between exposure from the external environment and uptake, storage and excretion with an organism (Zhou et al., 2008). 


\subsection{Aluminum (Al)}

Aluminum is not considered to be an essential element in humans. Exposure to aluminum has been implicated in a number of human pathologies including encephalopathy, dialysis dementia and Alzheimers disease (Narin et al., 2004). The results of Table 5 revealed that the concentration of accumulated $\mathrm{Al}$ in the gills of studied fish ranged from $(66.67 \pm 0.02)$ to $(175.00 \pm 0.05) \mu \mathrm{g} / \mathrm{g}$ dry weight. The highest concentration of $\mathrm{Al}$ was recorded in fish collected from site (4) in summer and the lowest $(66.67 \pm 0.02) \mu \mathrm{g} / \mathrm{g}$ dry weight was recorded in fish collected from site (3) in winter.

Table (5): Seasonal variations of aluminum $(\mathrm{Al})$ concentrations $(\mu \mathrm{g} / \mathrm{g}$ dry wt.) in tissues of $O$. niloticus fish from different sites of Lake Manzala.

\begin{tabular}{|c|c|c|c|c|c|}
\hline Tissues & $\begin{array}{c}\text { Sampling } \\
\text { site }\end{array}$ & Winter & Spring & Summer & Autumn \\
\hline \multirow{4}{*}{ 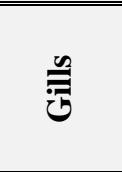 } & Lake 3 & $66.67 \pm 0.02$ & $68.53 \pm 0.01$ & $92.33 \pm 0.03$ & $106.00 \pm 0.04$ \\
\hline & Lake 6 & $70.00 \pm 0.03$ & $80.00 \pm 0.05$ & $100.00 \pm 0.06$ & $115.00 \pm 0.05$ \\
\hline & Drain1 & $109.00 \pm 0.06$ & $92.00 \pm 0.01$ & $163.53 \pm 0.03$ & $141.00 \pm 0.02$ \\
\hline & Drain 4 & $115.00 \pm 0.04$ & $100.00 \pm 0.06$ & $175.00 \pm 0.05$ & $155.00 \pm 0.02$ \\
\hline \multirow{4}{*}{ 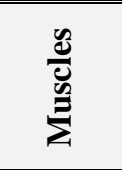 } & Lake 3 & $63.33 \pm 0.03$ & $45.85 \pm 0.05$ & $74.33 \pm 0.06$ & $76.60 \pm 0.05$ \\
\hline & Lake 6 & $70.00 \pm 0.04$ & $50.00 \pm 0.03$ & $80.00 \pm 0.06$ & $85.00 \pm 0.02$ \\
\hline & Drain 1 & $78.00 \pm 0.02$ & $58.00 \pm 0.02$ & $112.00 \pm 0.02$ & $110.00 \pm 0.02$ \\
\hline & Drain 4 & $66.67 \pm 0.02$ & $68.53 \pm 0.01$ & $120.00 \pm 0.05$ & $106.00 \pm 0.04$ \\
\hline
\end{tabular}

Data are represented as mean \pm S.E of 8 fishes $(\mu \mathrm{g} / \mathrm{g}$ dry wt.)

Also, the concentration of $\mathrm{Al}$ in muscles of $O$. niloticus fish ranged from $(45.85 \pm 0.05)$ to $(120.00 \pm 0.05) \mu \mathrm{g} / \mathrm{g}$ dry weight. 
The highest concentration was recorded in fish collected from site (4) in summer and the lowest was recorded in muscles of fish collected from site (3) in spring.Results indicated that the highest concentrations of $\mathrm{Al}$ was recorded in fish gills in summer at site (4); Bahr El-Baqur drain, which is contaminated by large quantity of sewage, agricultural and domestic effluent that contains large concentrations of Al. Also, the highest concentration of $\mathrm{Al}$ in gills of $O$. niloticus collected from different sites of Lake Manzala can be related to direct touch of polluted waters to gills, and accumulation of such metals from water primarily through fish gills. Lowest concentration of $\mathrm{Al}$ was recorded in $O$. niloticus fish muscles in spring season at site (3); Lake Manzala, which receives organic and inorganic pollutants. This variation in $\mathrm{Al}$ concentration maybe due to the nature of water source. In general, $\mathrm{Al}$ concentration in gills and muscles exceeded the permissible international level $(0.1 \mu \mathrm{g} / \mathrm{g})$ recommended by ANZECC and ARMCANZ (2000).

\subsection{Arsenic (As)}

Arsenic is actively metabolized in the tissue of fish especially in organs, such as liver and has the tendency to accumulate as reported in different fish. The results of Table 6 revealed that concentration of (As) in gills and muscles ranged from $(9.00 \pm 0.3)$ to $(15.50 \pm 0.6) \mu \mathrm{g} / \mathrm{g}$ dry weight in gills and $(6.72 \pm 0.6)$ to $(13.00 \pm 0.67) \mu \mathrm{g} / \mathrm{g}$ dry weights in muscles. Highest concentration was recorded in the gills of $O$. niloticus 
collected from site (4) in summer and the lowest was recorded in muscles of $O$. niloticus collected from site (3) in winter.

Authman et al. (2015) reported that total arsenic in marine fish, shellfish and freshwater fish tissues ranged from 0.19 to $65,0.2$ to 125.9 and 0.007 to $1.46 \mu \mathrm{g} / \mathrm{g}$ dry wt respectively. Arsenic also is known to induce a number of major stress protein families including heat shock proteins (Bamen et al., 2002).

Table (6): Seasonal variations of arsenic (As) concentrations ( $\mu \mathrm{g} / \mathrm{gdry}$ wt.) in tissues of $O$. niloticus fish from different sites of Lake Manzala.

\begin{tabular}{|c|l|c|c|c|c|}
\hline \hline Tissues & $\begin{array}{c}\text { sampling } \\
\text { site }\end{array}$ & Winter & Spring & Summer & Autumn \\
\hline \hline \multirow{3}{*}{} & Lake 3 & $10.17 \pm .0 .67$ & $11.27 \pm 0.58$ & $13.43 \pm 0.60$ & $11.17 \pm 0.40$ \\
\cline { 2 - 6 } & Lake 6 & $11.00 \pm 0.58$ & $11.60 \pm 0.06$ & $14.00 \pm 0.67$ & $11.50 \pm 0.30$ \\
\cline { 2 - 6 } & Drain1 & $13.00 \pm 0.60$ & $11.70 \pm 0.58$ & $14.87 \pm 0.67$ & $9.00 \pm 0.30$ \\
\cline { 2 - 6 } & Drain 4 & $13.50 \pm 0.67$ & $12.00 \pm 0.58$ & $15.50 \pm 0.60$ & $10.00 \pm 0.30$ \\
\hline \hline \multirow{2}{*}{} & Lake 3 & $6.72 \pm 0.60$ & $7.44 \pm 0.06$ & $10.63 \pm 0.30$ & $7.80 \pm 0.03$ \\
\cline { 2 - 6 } & Lake 6 & $7.00 \pm 0.13$ & $8.00 \pm 0.06$ & $13.00 \pm 0.67$ & $8.50 \pm 0.03$ \\
\cline { 2 - 6 } & Drain 1 & $10.33 \pm 0.60$ & $8.73 \pm 0.06$ & $11.17 \pm 0.30$ & $9.23 \pm 0.30$ \\
\cline { 2 - 6 } & Drain 4 & $11.00 \pm 0.60$ & $9.50 \pm 0.30$ & $12.00 \pm 0.60$ & $10.00 \pm 0.30$ \\
\hline
\end{tabular}

Data are represented as mean \pm S.E of 8 fishes $(\mu \mathrm{g} / \mathrm{g}$ dry wt.)

The highest concentrations of the accumulated As was found in the summer and the lowest was recorded in winter. The concentrations of As in muscles and gills of $O$. niloticus collected from different sites of Lake Manzala are higher than the permissible limits $(0.5 \mu \mathrm{g} / \mathrm{g})$ that recommended by ANZECC and ARMCANZ (2000). The concentrations of As in fish tissues in the present study was higher than that recorded previously by Authman et al. (2015), who reported that 
the total arsenic of freshwater fish tiusses ranged from 0.07 to 1.46 $\mu \mathrm{g} / \mathrm{g}$.

\subsection{Chromium $(\mathrm{Cr})$}

Chromium is an essential nutrient metal, necessary for metabolism of carbohydrates that potentiates insulin action (Farag $\boldsymbol{e t}$ al., 2006). The results of table (7) revealed that the concentration of Chromium $(\mathrm{Cr})$ in $O$. niloticus tissues (gills and muscles), collected from different sites of Lake Manzala during winter 2012 to autumn 2013 seasonally. The results revealed that the concentration of $\mathrm{Cr}$ in fish $O$. niloticus ranged from $(0.63 \pm 0.06)$ to $(1.60 \pm 0.01) \mu \mathrm{g} / \mathrm{g}$ dry wt. in gills and between $(0.53 \pm 0.01)$ to $(1.09 \pm 0.03) \mu \mathrm{g} / \mathrm{g}$ dry weights in muscles. The highest concentration was recorded in gills of fish collected from site (4) in summer and the lowest concentration was recorded in fish collected from site (3) in winter.

Table (7): Seasonal variations of chromium $(\mathrm{Cr})$ concentrations $(\mu \mathrm{g} / \mathrm{g}$ dry wt.) in tissues of $O$. niloticus fish from different sites of Lake Manzala.

\begin{tabular}{||c|l|c|c|c|c|}
\hline Tissues & Stations & Winter & Spring & Summer & Autumn \\
\hline \hline \multirow{3}{*}{} & Lake 3 & $0.63 \pm 0.06$ & $0.63 \pm 0.06$ & $1.43 \pm 0.01$ & $0.98 \pm 0.02$ \\
\cline { 2 - 6 } & Lake 6 & $0.75 \pm 0.06$ & $0.78 \pm 0.03$ & $1.38 \pm 0.03$ & $0.93 \pm 0.02$ \\
\cline { 2 - 6 } & Drain 1 & $0.64 \pm 0.06$ & $1.30 \pm 0.03$ & $1.54 \pm 0.03$ & $1.03 \pm 0.02$ \\
\cline { 2 - 6 } & Drain 4 & $0.85 \pm 0.03$ & $1.39 \pm 0.06$ & $1.60 \pm 0.01$ & $1.10 \pm 0.02$ \\
\hline \multirow{3}{*}{} & Lake 3 & $0.53 \pm 0.01$ & $0.68 \pm 0.05$ & $0.90 \pm 0.05$ & $0.73 \pm 0.05$ \\
\cline { 2 - 6 } & Lake 6 & $0.56 \pm 0.01$ & $0.63 \pm 0.01$ & $0.96 \pm 0.01$ & $0.76 \pm 0.06$ \\
\cline { 2 - 6 } & Drain 1 & $0.66 \pm 0.01$ & $0.69 \pm 0.03$ & $1.06 \pm 0.03$ & $0.65 \pm 0.05$ \\
\cline { 2 - 6 } & Drain 4 & $0.69 \pm 0.05$ & $0.67 \pm 0.01$ & $1.09 \pm 0.03$ & $0.63 \pm 0.05$ \\
\hline
\end{tabular}

Data are represented as mean \pm S.E of 8 fishes $(\mu \mathrm{g} / \mathrm{g}$ dry wt.) 
The highest values of $\mathrm{Cr}$ concentrations were recorded in gills of $O$. nilotius in summer at site (4) and the lowest values were recorded in muscles at site (3) in winter. The concentrations of $\mathrm{Cr}$ in $O$. niloticus tissues at all seasons in all sites were higher than the permissible levels (0.15 $\mu \mathrm{g} / \mathrm{g}$ dry wt.) recommended by ANZECC and ARMCANZ (2000).

\subsection{Cobalt (Co)}

The result of Table 8 revealed that the concentration of Cobalt (Co) in fish tissues ranged between $(51.33 \pm 0.58)$ to $(100.00 \pm 0.60) \mu \mathrm{g} / \mathrm{g}$ dry wt. in gills and $(11.00 \pm 0.30)$ to $(50.00 \pm 0.58)$ in muscles. The highest concentrations was recorded in gills fish collected from site (4) in summer and lowest was recorded in gills fish collected from site (3) in winter.

Table (8): Seasonal variations of cobalt $(\mathrm{Co})$ concentration $(\mu \mathrm{g} / \mathrm{gdry}$ wt.) in tissues of $O$. niloticus fish from different sitesof Lake Manzala.

\begin{tabular}{|c|c|c|c|c|c|}
\hline Tissues & $\begin{array}{c}\text { sampling } \\
\text { site }\end{array}$ & Winter & Spring & Summer & Autumn \\
\hline \multirow{4}{*}{ 昜 } & Lake 3 & $51.33 \pm 0.58$ & $61.67 \pm 0.60$ & $80.33 \pm 0.60$ & $73.00 \pm 0.58$ \\
\hline & Lake 6 & $55.00 \pm 0.58$ & $65.00 \pm 0.60$ & $85.00 \pm 0.60$ & $75.00 \pm 0.58$ \\
\hline & Drain1 & $59.00 \pm 0.58$ & $77.00 \pm 0.60$ & $95.83 \pm 0.60$ & $68.00 \pm 0.58$ \\
\hline & Drain 4 & $62.00 \pm 0.60$ & $80.00 \pm 0.58$ & $100.00 \pm 0.60$ & $75.00 \pm 0.52$ \\
\hline \multirow{4}{*}{ 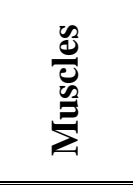 } & Lake 3 & $11.00 \pm 0.30$ & $37.00 \pm 0.30$ & $43.00 \pm 0.58$ & $36.50 \pm 0.48$ \\
\hline & Lake 6 & $15.00 \pm 0.30$ & $42.00 \pm 0.60$ & $48.00 \pm 0.48$ & $42.00 \pm 0.60$ \\
\hline & Drain 1 & $26.00 \pm 0.60$ & $12.00 \pm 0.30$ & $43.80 \pm 0.6$ & $13.00 \pm 0.30$ \\
\hline & Drain 4 & $30.00 \pm 0.58$ & $16.00 \pm 0.30$ & $50.00 \pm 0.58$ & $15.00 \pm 0.30$ \\
\hline
\end{tabular}

Data are represented as mean \pm S.E of 8 fishes $(\mu \mathrm{g} / \mathrm{g}$ dry wt.) 
Cobalt concentration in fish tissues (gills and muscles) were higher than the permissible levels $(1.2 \mu \mathrm{g} / \mathrm{g})$ that recommended by ANZECC and ARMCANZ (2000). The present results of Co agreed with that of El- Moselhy (1999) and Ali (2008) on O. niloticus from lake Manzala which was from 0.32 to $0.89 \mu \mathrm{g} / \mathrm{g}$.

\subsection{Nickel (Ni):}

Nickel released from the process of nickel mining and by industries that convert scrap or new nickel into alloys or nickel compounds or by industries that use nickel and its compounds. These industries may also discharge nickel into wastewater. Once Nickel released to the environment it forms complexes with many ligands, making it more mobile than most heavy metals, (Palaniappan and Karthikeyan, 2009). Table (9) shows the concentrations of Nickel (Ni) in gills and muscles of $O$. niloticus fish collected from different sites of Lake Manzala during the period winter 2012 to autumn 2013. The concentration of (Ni) ranged between $(65.00 \pm 0.03)$ to $(100.00 \pm 0.03) \mu \mathrm{g} / \mathrm{g}$ dry wt. in the gills, while from $(40.0 \pm 0.03)$ to $(90.00 \pm 0.03) \mu \mathrm{g} / \mathrm{g}$ dry wt. in the muscles. The highest concentration was recorded in gills of $O$. niloticus collected from site (6) in winter and the lowest recorded in muscles of fish collected site (6) in spring. 
Table (9): Seasonal variations of nickel $(\mathrm{Ni})$ concentrations $(\mu \mathrm{g} / \mathrm{gdry}$ wt.) in tissues of $O$. niloticus fish during the study from different sites of Lake Manzala.

\begin{tabular}{|c|l|c|c|c|c|}
\hline Tissues & $\begin{array}{c}\text { samplin } \\
\text { g site }\end{array}$ & Winter & Spring & Summer & Autumn \\
\hline \hline \multirow{3}{*}{} & Lake 3 & $95.50 \pm 0.04$ & $66.67 \pm 0.05$ & $65.00 \pm 0.03$ & $69.00 \pm 0.30$ \\
\cline { 2 - 6 } & Lake 6 & $100.00 \pm 0.03$ & $70.00 \pm 0.04$ & $68.00 \pm 0.05$ & $75.00 \pm 0.05$ \\
\cline { 2 - 6 } & Drain1 & $81.60 \pm 0.6$ & $75.40 \pm 0.06$ & $70.00 \pm 0.30$ & $86.00 \pm 0.03$ \\
\cline { 2 - 6 } & Drain 4 & $85.00 \pm 0.04$ & $85.00 \pm 0.05$ & $75.00 \pm 0.03$ & $90.00 \pm 0.05$ \\
\hline \hline \multirow{2}{*}{} & Lake 3 & $55.50 \pm 0.06$ & $40.00 \pm 0.03$ & $45.00 \pm 0.06$ & $43.00 \pm 0.05$ \\
\cline { 2 - 6 } & Lake 6 & $60.00 \pm 0.05$ & $50.00 \pm 0.03$ & $50.00 \pm 0.50$ & $50.00 \pm 0.03$ \\
\cline { 2 - 6 } & Drain 1 & $55.00 \pm 0.50$ & $60.00 \pm 0.60$ & $65.00 \pm 0.04$ & $85.00 \pm 0.05$ \\
\cline { 2 - 6 } & Drain 4 & $50.00 \pm 0.20$ & $65.00 \pm 0.05$ & $70.00 \pm 0.06$ & $90.00 \pm 0.30$ \\
\hline
\end{tabular}

Data are represented as mean \pm S.E of 8 fishes $(\mu \mathrm{g} / \mathrm{g}$ dry wt.)

The concentrations of $\mathrm{Ni}$ in gills and muscles of $\mathrm{O}$. niloticus collected from different sites of Lake Manzala are higher than the permissible limit $(0.4 \mu \mathrm{g} / \mathrm{g}$ dry wt.) recommended by ANZECC and ARMCANZ (2000).

\subsection{Selenium (Se):}

Selenium is widely distributed throughout the environment and is found in most ground and surface waters at concentrations between 0.1 and $0.4 \mu \mathrm{g} / \mathrm{L}$ of Se (Muscatellos and Janz, 2009). The results of Table (10) revealed that the concentration of (Se) ranged between $(0.60 \pm$ $0.05)$ to $(2.67 \pm 0.002) \mu \mathrm{g} / \mathrm{g}$ dry weight. The highest concentration of (Se) was recorded in muscles of fish collected from site (1) in summer and in gills of fish from site (3) in winter. These concentrations are higher than the permissible levels $(1.0 \mu \mathrm{g} / \mathrm{g}$ dry wt.) recommended by 
ANZECC and ARMCANZ (2000). For all sites the Se concentrations in muscles were lower than the permissible levels in winter.

Table (10): Seasonal variations of selenium (Se) concentration $(\mu \mathrm{g} / \mathrm{g}$ dry wt.) in tissues of O. niloticus fish from different sites of Lake Manzala.

\begin{tabular}{|c|c|c|c|c|c|}
\hline Tissues & $\begin{array}{c}\text { sampling } \\
\text { site }\end{array}$ & Winter & Spring & Summer & Autumn \\
\hline \multirow{4}{*}{$\stackrel{0}{0}$} & Lake 3 & $0.64 \pm 0.05$ & $0.96 \pm 0.05$ & $1.38 \pm 0.05$ & $0.7 \pm 0.05$ \\
\hline & Lake 6 & $0.78 \pm 0.02$ & $0.80 \pm 0.05$ & $1.50 \pm 0.02$ & $0.82 \pm 0.01$ \\
\hline & Drain1 & $0.94 \pm .05$ & $0.85 \pm 0.02$ & $1.54 \pm 0.01$ & $0.74 \pm 0.01$ \\
\hline & Drain 4 & $0.90 \pm 0.05$ & $0.92 \pm 0.06$ & $1.68 \pm 0.03$ & $0.85 \pm 0.02$ \\
\hline \multirow{4}{*}{$\begin{array}{l}\frac{\tilde{e}}{e} \\
\frac{0}{0} \\
\sum\end{array}$} & Lake 3 & $1.83 \pm 0.01$ & $1.88 \pm 0.01$ & $2.10 \pm 0.06$ & $1.96 \pm 0.06$ \\
\hline & Lake 6 & $1.95 \pm 0.05$ & $1.70 \pm 0.02$ & $1.85 \pm 0.05$ & $2.00 \pm 0.05$ \\
\hline & Drain 1 & $2.23 \pm 0.01$ & $1.98 \pm 0.01$ & $2.67 \pm 0.06$ & $1.96 \pm .06$ \\
\hline & Drain 4 & $2.50 \pm 0.05$ & $2.20 \pm 0.01$ & $2.40 \pm 0.06$ & $1.80 \pm 0.05$ \\
\hline
\end{tabular}

Data are represented as mean \pm S.E of 8 fishes $(\mu \mathrm{g} / \mathrm{g}$ dry wt.)

It is clear from the present study that gills of $O$. niloticus has a higher tendency to accumulate heavy metals more than muscles, and the order of metals in accumulation follows the concentrations pattern $\mathrm{Al}>\mathrm{Ni}>\mathrm{Co}>\mathrm{As}>\mathrm{Se}$ and $\mathrm{Cr}$. The basic reason for this, is the external position and its proximately to ambient toxicant in addition, the highly branched structural of organization gill and resultant highly increased surface area along the large volume of water passing of the gill surface as well as the relatively small biomass when compared to their surface area( Jayakumar and Paul, 2006). The present results agree with that of Gad and yacoub (2009). Lower accumulation of Al, Ni, Co, As, Se and $\mathrm{Cr}$ in fish muscles may be attributed to various reasons; firstly the 
muscles do not come into direct contact with the toxicant, secondly the muscles is not an active site for detoxification and therefore transport of heavy metals from other tissues to muscles does not seen to be occurred (Jayakumar and Paul, 2006). Moreover, metal accumulation in fish is not only depends on the types of metals and its concentrations in water, but also on the structure of the tissues and organs and the interaction of heavy metals in the environment (Karayakos and Aya, 2004). The present results agree with the results of Gad (2007) and Gad and Yacob (2009).

\section{CONCLUSION AND RECOMMENDATION}

The pollution of the southern region of Lake Manzala by agricultural, industrial and sewage wastes causes accumulation of large quantity of heavy metals in water and fish muscles (edible parts), that exceeded the maximum permissible limits recommended by ANZECC and ARMCANZ (2000), and this causes harmful impact on human. So, the following recommendations should be taken into consideration to protect and maintain the quality of aquatic environment in the Lake Manzala and reduce the risk of pollution:

[1] Carrying out an intensive plan for monitoring water quality of aquatic environment especially in northern lakes; seasonally and regionally.

[2] The Egyptian Environmental Affairs Agency (EEAA) should attend in all international conventions to prohibit the excessive usage of the environmental pollutants and to restrict discharging of wastewater 
(sewage, industrial, domestic and agriculturally) into the River, canals and lakes without being treated according to the international standards including the Egyptian laws No. 48 (1982) and No. 4 (1994) for protection of the aquatic environment.

[3] Continuous evaluation of the water quality and other aquatic environment components especially the biota should be carried out to ensure ecological system integrity.

\section{REFERENCES}

Abbasssy, M. S; Ibrahim, H. Z. and Abdel Kader, H. M. (2003): Persistent ogranochlorine pollutants in aquatic ecosystem of lake Manzala, Egypt. Bull. Environment, Toxical., 70:11581164.

Abdel- Azeem, A. M.; Abdel Moneim, T. S.; Ibrahim, M. E.; Hassn, M. A. and Salah, M. Y. (2007): Effect of long term heavy metal concentration on Diversity of Terricolous Fungi and Nematodes in Egypt. A case study. Water Air Soil Pollut. Journal, 186: 233-254.

Abdel-Shafy, H. I. and R. O. Aly (2002): Water issue in Egypt: Resources, pollution andprotection endeavors. CEJOEM, 8(1): 3-21.

Al-Attar, A. M. (2007): The influence of Nickel exposure on selected physiological parameters and gill structures in the telost fish Oreochromis niloticus.J. Biol. Sci., 7:77-85

Ali, M. H. H. and Fishar, M. R. (2005): Accumnlation of Trace metals in some benthic invertebrates and fish species relevant to their concentration in water and sediment of Lake Qarum Egypt. J.Aquat .Res., 31:289.302. 
Ali, M. H. (2008): Assessment of some water quality characteristics and determination of some heavy metals in Lake Manzala , Egypt . J.Aquat .Biol \&Fish, 12(2):133-154.

ANZECC and ARMCANZ. (2000): Australian and New Zealand Environment and Conservation Council\& Agriculture and Resource Management Council of Australia and New Zealand, Canberra, Australia.

APHA. (2012): Standard Methods for Examination of Water and Wastewater. 22 ${ }^{\text {nd }}$ ed. Washington: American Public Health Association; $1360 \mathrm{pp}$.

Authman, M. M.N.; Zaki, M.S.; Khallaf, E.A. and Abbas, H. H. (2015): Use of fish as Bio indictor of the effect of heavy metals pollution: J. Aquaculture Research \& Development, 6: (328).

Bamen , J .A; Collins, B. W.; Dix ,D .J. and Allen, J. W. (2002): Effect of heat shock protein 70 (Hsp 70) an arsenite induced genotoxicity Environment. Mol. Mutag., 40 : 236-242 .

Boran, M. and Altinok, I. (2010): A review of heavy metals in water, sediment and living organisms in the Black Sea, Turkish, Journal of Fisheris and Aquatic Sciences, 10(4): 565-572.

El-Moselhy, K. M. (1999): Levels of some metals in fish Tilapia Sp. Caught from certain Egyptian Lakes and River Nile. Egypt. J. Aquat. Biol, Fish. 3(1): 73-83.

Farag, M.; May, T.; Mary, G.D.; Easton, M. and Hatrper, P.P. (2006): The effect of chronic chromium exposure on the health of chimaok salmon (oncrhynchus tshawyfscha). Aquatic. Toxical, 76: 246-257.

Gad, N. S. (2007): Assessment of some pesticides and heavy metals in water and tissues of Oreochroumis aureus from aquatic drainage and Nile canals and their impact on some biochemical parameters. J.Egypt. Ger, Soc. Zool., (53 A):325-346. 
J. Environ. Sci.

Institute of Environmental Studies and Research - Ain Shams University

Gad, N. S. (2005): Impact of environmental pollution in the southern region of Lake Manzala. Egypt on some biochemical parameters of Tilapia Zilli. J. Egypt Ger.Soc. Zool., Vol. 48( A). Comparative Physiology, 279-298.

Gad, N. S. and Yacoub, A. M. (2009): Antioxidant defense agents and biochemical responses of fish to pollution of Rosetta Branch of River Nile Egypt., J. Aquat. Biol \& Fish, 13 (4): 109-128.

Hamed, Y.A.; Abdel Moneim, T.S.; El-Kiki, M.H.; Hassan, M.A. and Berndtsson, R. (2013): Assessment of Heavy Metals Pollution and Microbial Contamination in Water, Sediments and Fish of Lake Manzala, Egypt Life Science Journal, 10 (1):86-99.

Jayakumar, P. and Paul, V. (2006): Patterns \& Cadmium accumulation in selected tissues of the cat fish Clarius batrachus exposed to sub lethal concentration of cadmium chloride. Vet. Archive, 76:167-177.

Karayakos, B. and Aya, O. (2004): Effect of lead and cadmium interaction of the metal accumulation in tissues and organs of Nile Tilapia Oreochromis niloticus. Bull . Environ. Contan \& Toxical, 12:1414-148.

Muscatellos, J.R. and Janz, D.M. (2009): Selenium accumulation in aquatic biota down stream of uranium mining and milling operation. Sci. Total Environ, 407:1318-1325.

Narin, I.; Tuzen , M. and Saylak, M. (2004): Aluminum Determination in environmental samples by graphite furnace atomic absorption spectrometry after solid phase extraction on amberlite xad-1180/pyroctrchol violet chelatiny resin. Talanta, 63:411-418.

Palaniappam, P. L. R. and Karthikeyan, S. (2009): Bioaccumulation and depuration of chromium in the selected organs and whole body tissues of fresh water fish Cirrhinus mrigala individually and in binary solution with Nickel. J.Environ.Sci., 21:229-236. 
Saeed, S. M., and Shaker, I. M. (2012): Assessment of heavy metals pollution in water and sediement and their effect on Oreochromis niloticus in the northern Delta lakes. Egypt. $8^{\text {th }}$ Inter. Symp. On Tilapia in Aqu., pp. 475-489.

Zahran, M. A.; El-Amier, Y. A.; Elnaggar, A. A.; Abd El-Azim, H. and El-Alfy, M. A. (2015): Assessment and Distribution of Heavy Metals Pollutants in Manzala Lake, Egypt. Journal of Geoscience and Environment Protection, 3,107-122.

Zhou, O.; Zhang, J.; FU, J.; SHI, J. and Jiang (2008): Review Bio monitoring .An appealing tool for assessment of metals pollution in the aquatic ecosystem .Analytica Chinica Acta, 606: $135-150$ 


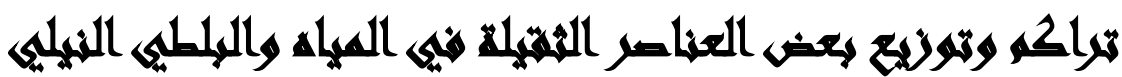

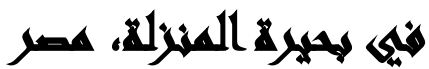

[1]

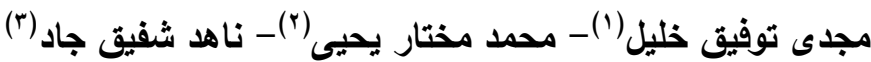

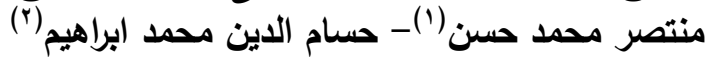

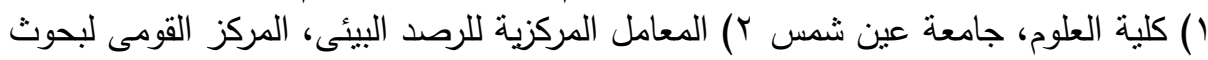

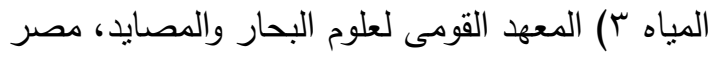

\section{المستصنص}

تعنبر بحيرة المنزلة احدى البحيرات الثمالية الهامة في مصر من الناحية الاقتصادية

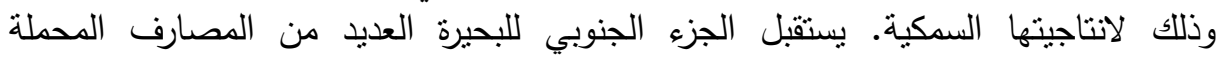

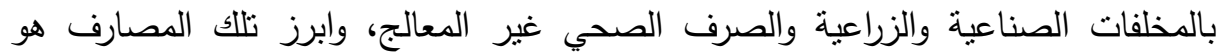

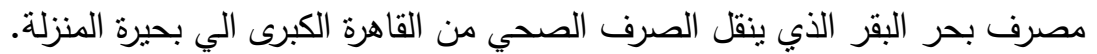

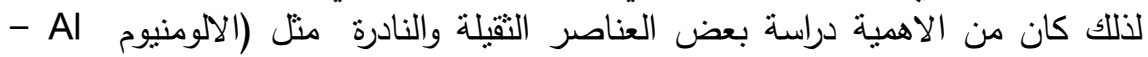

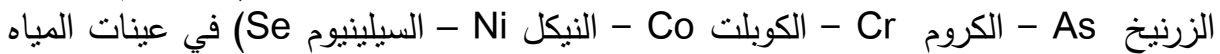

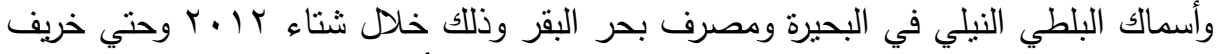

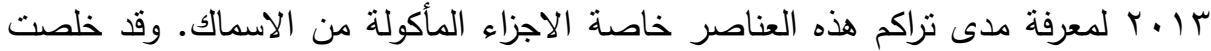

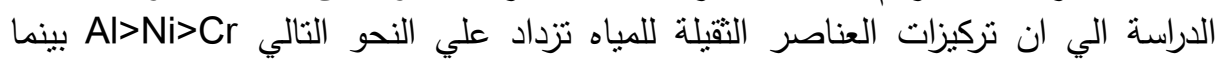

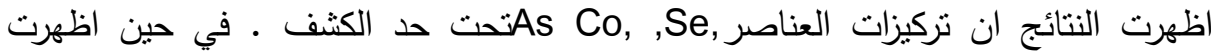

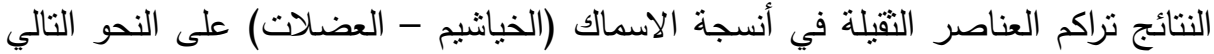
Al>Ni>Co>As>Se>Cr يمثل خطرا مباشرا على صحة الافراد الذين يعتمدوا علي الاسماك كوجبات أساسية في هذه الهن 